\title{
Three new species of Neodrassex (Araneae, Gnaphosidae) from Brazil
}

\author{
Ricardo Ott
}

Museu de Ciências Naturais, Fundação Zoobotânica do Rio Grande do Sul. Rua Dr. Salvador França, 1427, 90690-000 Porto Alegre, RS, Brazil. (rott@fzbb.rs.gov.br)

\begin{abstract}
Three new species of Neodrassex Ott, 2012 are described from Brazil: N. cachimbo sp. nov. from state of Pará, N. nordeste sp. nov.
\end{abstract} from state of Piauí and N. ibirapuita sp. nov. from state of Rio Grande do Sul.

KEYWORDS. Leptodrassex group, Neotropical Region, spiders, taxonomy.

RESUMO. Três espécies novas de Neodrassex (Araneae, Gnaphosidae) do Brasil. Três espécies novas de Neodrassex Ott, 2012 são descritas para o Brasil: N. cachimbo sp. nov. do estado do Pará, N. nordeste sp. nov. do estado do Piauí e N. ibirapuita sp. nov. do estado do Rio Grande do Sul.

PALAVRAS-CHAVE. Grupo Leptodrassex, Região Neotropical, aranhas, taxonomia.

Neodrassex was proposed by Отт (2012) to include two species from South America belonging to the Leptodrassex group, which at that time was known exclusively from the Mediterranean, Canary Islands and Asia (Murphy, 2007). Until now Leptodrassex Murphy, 2007 and Neodrassex Ott, 2012 are the only genera included at this group, which was proposed by Murphy (2007). According to the same author, Leptodrassex species are similar to Leptodrassus Simon, 1878 but differ from these ones primarily because of their unusual dentition, with 2-4 "discrete small" teeth on the promargin of the chelicerae and 2-3 teeth on the retromargin. A similar but not identical pattern was found by Отт (2012) for the species of the South American Neodrassex, in which the known pattern is 2-3 teeth at the promargin and 2-4 teeth at the retromargin of the chelicerae.

In the general aspect species of the Leptodrassex group are pale and small spiders usually with the anterior median eyes surrounded with black pigmented area; males lacks the abdominal dorsal scutum and the palp presents a single retrolateral tibial apophysis and large, rounded and ventrally projected bulb. Females of Leptodrassex group can be identified by the shape of the internal female genitalia with rounded spermathecae head and long and straight, posteriorly directed, fertilization ducts (Murphy, 2007; OTT, 2012). Although the males of the Leptodrassex group share very similar appearance and palp shape, the Leptodrassex females differs from Neodrassex ones by the external shape of the female genitalia, the latter characterized by the presence of lateral epigynal processes combined with a large atrium divided by a narrow median septum (see Отт, 2012).

In this study, three new species of Neodrassex are described based on specimens from Brazilian states of Pará, Piauí and Rio Grande do Sul, discovered in a recent review of the Gnaphosidae of Museu Paraense Emílio Goeldi spider collection and the recently collected material of the Pampa Biome (Museu de Ciências Naturais PELD project - "APA do Ibirapuitã").

\section{MATERIAL AND METHODS}

The specimens examined are deposited in the arachnological collection of the Museu de Ciências Naturais, Fundação Zoobotânica do Rio Grande do Sul, Porto Alegre, Rio Grande do Sul, Brazil (MCN; R. Ott) and Museu Paraense Emílio Goeldi, Belém, Pará, Brazil (MPEG; A. B. Bonaldo). The description format follows Отт (2012). Only leg articles with spines are indicated. All femoral dorsal spines are considered erect and bristle-like; all remaining article spines are considered surface bearing. The female epigyna and male palp were dissected and immersed in clove oil for clearing in order to facilitate the study and imaging of its structures.

Text abbreviations: AME, anterior median eye; ALE, anterior lateral eye; PM, cheliceral promargin; PLE, posterior lateral eye; PME, posterior median eye; RM, cheliceral retromargin; MA, median apophysis; RTA, retrolateral tibial apophysis.

Incident light images were taken through a stereomicroscope with attached camera and processed with Helicon Focus multi-range program. Transmitted light images of cleared female epigyna and male palp were taken with a compound microscope using a digital camera and also processed with Helicon Focus. Drawings were made using printed images as models and compound microscope and stereomicroscope as three dimensional shape confirmation tools. Electron scanning microscope (SEM) images were taken using a Jeol-JSM-5200 with attached SLR digital camera. All measurements are in millimeters. 


\section{Neodrassex Ott, 2012}

Neodrassex Oтt, 2012:344; Platnick, 2013.

Type-species: Neodrassex aureus by original designation (Отт, 2012).

\section{Neodrassex cachimbo sp. nov.} (Figs 1-14)

Type material. Holotype $\hat{\sigma}$ from Campo de Provas Brigadeiro Velloso, Serra do Cachimbo, Novo Progresso, Pará, Brazil (09²2'24”S - 55 01'10”W), 12.IX.2003, A. B. Bonaldo col. (MPEG 3812) (sample: SE. CA. 0060 - manual night sampling).

Etymology. The noun in apposition refers to the type locality, Serra do Cachimbo, state of Pará.

Diagnosis. Males of $N$. cachimbo sp. nov. are close to N. aureus Ott, 2012 but can be distinguished by presence of three teeth on the PM and two on the RM. The species can be also recognized by shape of the male palp, with cymbium one and a half times the length of bulb, with conspicuous membranous conductor close to MA and by the broader RTA (Figs 3-11).

Description. Male (MPEG 3812, holotype). Coloration (Figs 1-2): carapace, sternum yellowish with dark borders; endites, chelicerae yellowish, coxae and femora yellowish, remaining leg articles light brown. Abdomen, dorsal: pale yellow with olivebrown spotted areas near posterior portion. Abdomen, ventral: pale yellow with olive-brown spotted areas surrounding spinnerets. Total length 1.98. Carapace 0.99 long, 0.76 wide. Eye diameters and interdistances: AME 0.10, ALE 0.08, PME 0.08, PLE 0.08, AMEAME 0.08, AME-ALE 0.02, PME-PME 0.08, PMEPLE 0.04, ALE-PLE 0.01. Leg measurements: I femur 0.73 / patella $0.36 /$ tibia 0.59 / metatarsus 0.50 / tarsus $0.36 /$ total 2.54 ; II $-0.73 / 0.36 / 0.59 / 0.50 / 0.36 /$ 2.54; III $-0.59 / 0.30 / 0.43 / 0.43 / 0.23 / 1.98$; IV $-0.92 /$ $0.36 / 0.69 / 0.73 / 0.26 / 2.96$. Leg spination: femora, I-II d1-0-0, III-IV d1-0-2, IV r0-0-1; tibiae, I-II v2-2-0, III v1-1-0, p1-1-1, r1-0-1, IV v0-1-2, p-r1-0-1; metatarsus, I-II v2-0-0, III d2-0-2, v2-1-0, p1-0-2, r0-0-1, IV d1-00 , p-r1-0-2. Distal-prolateral half of femur, prolateral side of patela and proximal-retrolateral half of tibia covered by innumerous, irregularly placed trichobotria. Palp spination: femur, d1-1-1. Palp: tibia with broad prolateral distal border; broad, stout and hooked retrolateral tibial apophysis (Figs 4, 5, 9-11); cymbium almost one and a half times as long as the bulb; bulb rounded, longer than wide; tegulum more sclerotized than subtegulum; distally with inconspicuous oblique sclerotized ridge surronding MA, which is flat, translucid and slightly hooked, originating on distalretrolateral portion of tegulum; conductor membranous, slightly curved and darker than MA, originating basally to the embolus and prolaterally to MA (Figs 4-6, 12-14); embolus stout, well sclerotized, distally " $\mathrm{C}$ " shaped on stereo microscope (Fig. 4) and rounded at SEM (Figs 9, 13, 14), embolic duct between embolus distal "C" shaped portion (Figs 9, 12-14), distal portion of embolus bearing at last two membranous structures at tip, surrounding the spermatic opening (collapsed at SEM preparation images) (Figs 3-8, 12-14).

Female. Unknown.

Distribution. Known only from the type locality.

Note: A male embolic conductor was not clearly identified in the type-species $N$. aureus by Отт (2012). Considering the position and shape of the conductor of $N$. cachimbo sp. nov., the conductor of $N$. aureus is possibly a small triangular membranous structure positioned posteriorly and basal to the embolus (Fig. 15; see also Отт, 2012: 345, figs 12, 13, 15).

Natural history. Unknown.

\section{Neodrassex ibirapuita sp. nov. (Figs 16-21)}

Type material. Holotype + from Estância do Açude, Área de Proteção Ambiental do Rio Ibirapuitã, Sant'Ana do Livramento, Rio Grande do Sul, Brazil (30²8'49”S - 55'33'06”'W), 15.XI.2011 Eq. PELD (I. Heydrich, M. Pairet, P. Bueno, R. Ott) col., deposited in MCN 49393 (sample: C2-5).

Etymology. The noun in apposition refers to the type locality, "Área de Proteção Ambiental do Rio Ibirapuitã".

Diagnosis. $N$. ibirapuita sp. nov. is close to $N$. aureus and N. iguatemi Ott, 2012 by the shape of the epigynal plate; differs from both species by the short septum dividing only the anterior portion of atrium (Figs 18-21), by presence of three teeth on the PM and two at PM and by the absence of femoral spines.

Description. Female (MCN 49393). Coloration: carapace, sternum, endites, chelicerae yellowish; leg femora yellowish, remaining articles slightly darker; abdomen, dorsal and ventral pale yellow, posterior area slightly dark olive-brown (Figs 16, 17). Total length 3.08. Carapace 0.99 long, 0.60 wide. Eye diameters and interdistances: AME 0.10, ALE 0.08, PME 0.08, PLE 0.08; AME-AME 0.06, AME-ALE 0.02, PME-PME 0.04, PME-PLE 0.04, ALE-PLE 0.01 . Leg measurements: I - femur 0.70 / patella 0.33 / tibia 0.50 / metatarsus 0.43 / tarsus 0.33 / total 2.29 ; II - 0.70/ 0.33/ 0.50/ 0.43/ 0.33/ 2.29; III - 0.56/0.26/ $0.40 / 0.36 / 0.26 / 1.84$; IV $-0.89 / 0.36 / 0.73 / 0.76 /$ $0.30 / 3.04$. Leg spination: tibiae, I-II v2-2-0, III v11-0, p1-1-1, VI v0-1-2, p0-0-1; metatarsi, I-II v2-00, III-IV d1-0-2, III-IV p0-1-1, III v2-0-1, IV v0-1-2. Palp spination: tibia, v 1-0-0, p1-1-0; tarsus, v1-0-2, p2-0-0, r1-0-0. Epigynal plate wider than long, broader posteriorly, semicircular atrium divided by narrow 
septum anteriorly; copulatory openings positioned on posterior portion of epigynum, as large as copulatory ducts in width; lateral epigynal processes as large as spermatecae width (Figs 18, 20); internal genitalia with relatively small, oval spermathecae; copulatory ducts relatively short, curved, narrowing toward spermathecae; fertilization ducts posteriorly directed (Figs 19, 21).

Male. Unknown.

Distribution. Known only from the type locality.

Natural history. Specimen was collected in Pampa Biome grassland area.
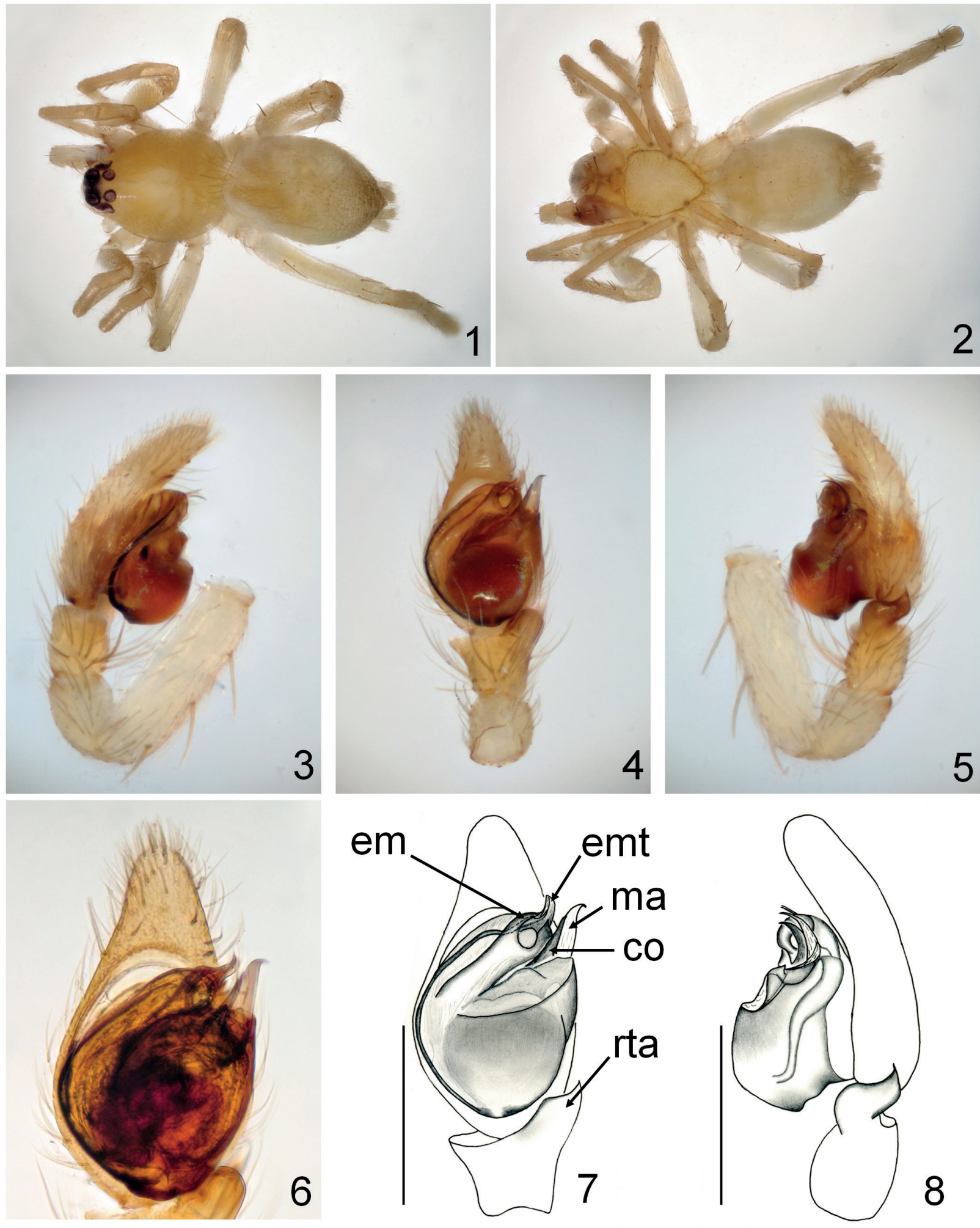

Figs 1-8. Neodrassex cachimbo sp. nov. (holotype ${ }^{7}$, MPEG 3812): 1, dorsal; 2, ventral; palp: 3, prolateral; 4, 6, 7, ventral; 5, 8, retrolateral Scales $=0.20 \mathrm{~mm}$ (co, conductor; em, embolus; emt, embolus membranous tip; ma, median apophysis; rta, retrolateral tibial apophysis). 

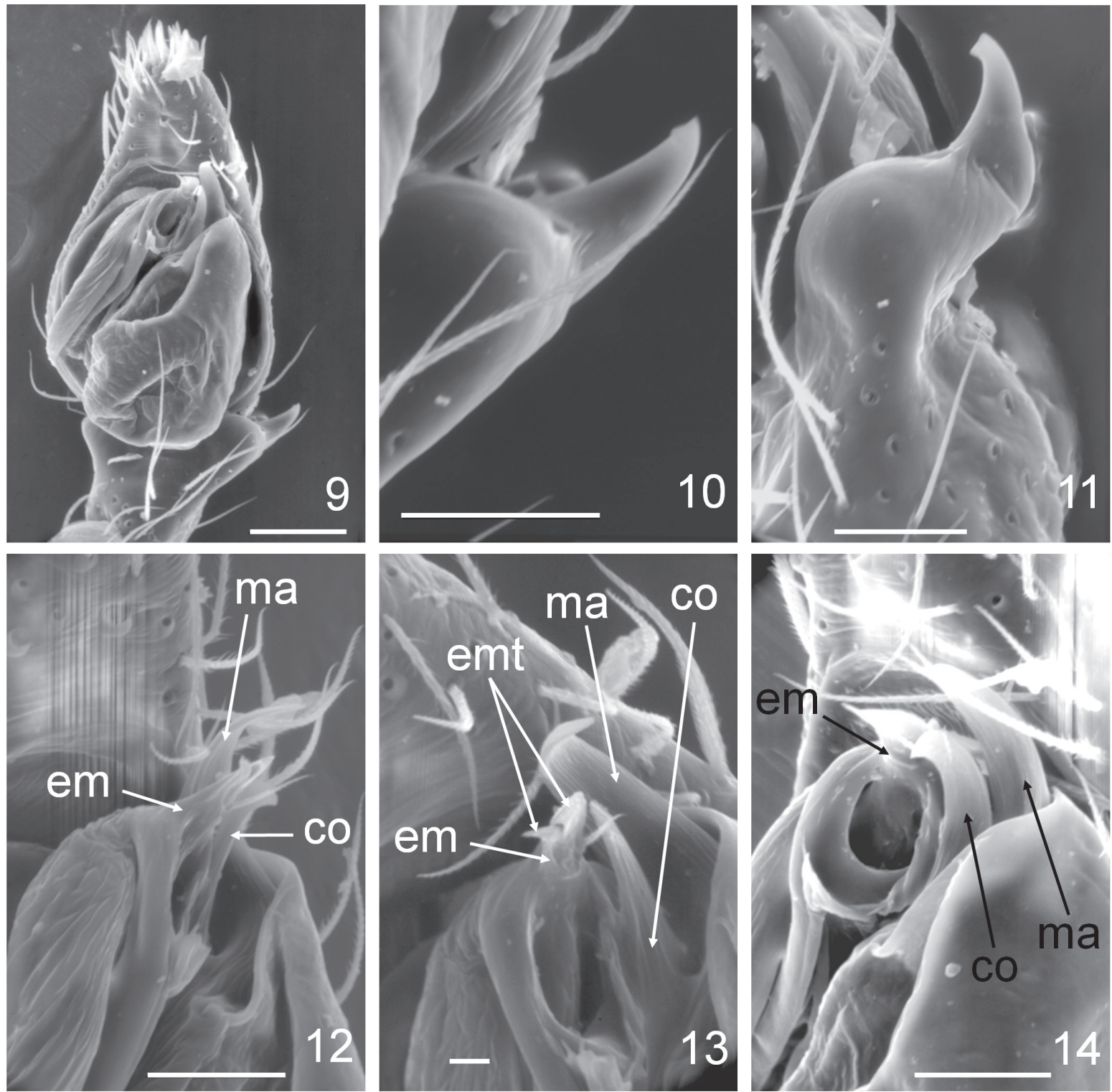

Figs 9-14. Neodrassex cachimbo sp. nov., male palp, scanning electron microscope images: 9, ventral; retrolateral tibial apophysis: 10, ventral; 11, retrolateral; distal portion of bulb: 12, prolateral; 13, ventral; 14, retrolateral. Scales: Fig. $9=0.10 \mathrm{~mm} ; 10-12,14=0.05 \mathrm{~mm} ; 13=0.01 \mathrm{~mm}$ (co, conductor; em, embolus; emt, embolus membranous tip; ma, median apophysis).

\section{Neodrassex nordeste sp. nov.}

(Figs 22-27)

Type material. Holotype $\odot$ from Parque Nacional das Sete Cidades, Brasileira e Piracuruca, Piauí, Brazil

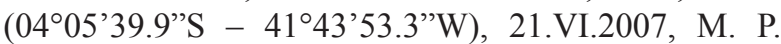
Albuquerque col., deposited in MPEG 21847 (sample: PN7C 1181). Paratype + , same locality and collector data of holotype, 24.I.2007 (MPEG 21486; sample: PN7C 0767).

Etymology. The noun in apposition refers to the Brazilian Northeast Region - "Região Nordeste" where state of Piauí is located.

Diagnosis. Neodrassex nordeste sp. nov. is close to N. iguatemi Ott, 2012 by the general shape of the female genitalia and to $N$. ibirapuita sp. nov. by the presence of three teeth on the PM and two teeth

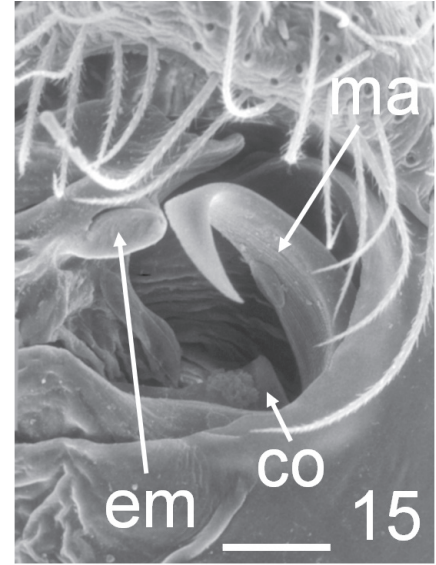

Fig. 15. Neodrassex aureus Ott, 2012, scanning electron microscope image of male palp, ventral view; detail indicating the possible conductor homologous structure not indicated by Ott (2012). Scale: 0.10 $\mathrm{mm}$ (co, conductor; em, embolus; ma, median apophysis). 
on the RM; the species differs from the former by the different teeth number on PM and by the shape of the posterior portion of the epigynal plate, with differently shaped copulatory openings, and from the latter by the larger copulatory openings and by the lateral epigynal processes proportionally smaller than the spermathecae (Figs 24-27).

Description. Female (MPEG 21487). Coloration: carapace, sternum, endites, chelicerae yellowish, leg femora yellowish, remaining articles slightly darker. Abdomen, dorsal, ventral: pale yellow, dorsally posterior portion slightly suffused with olive-brown (Figs 22, 23). Total length 2.63. Carapace 1.02 long, 0.85 wide. Eye
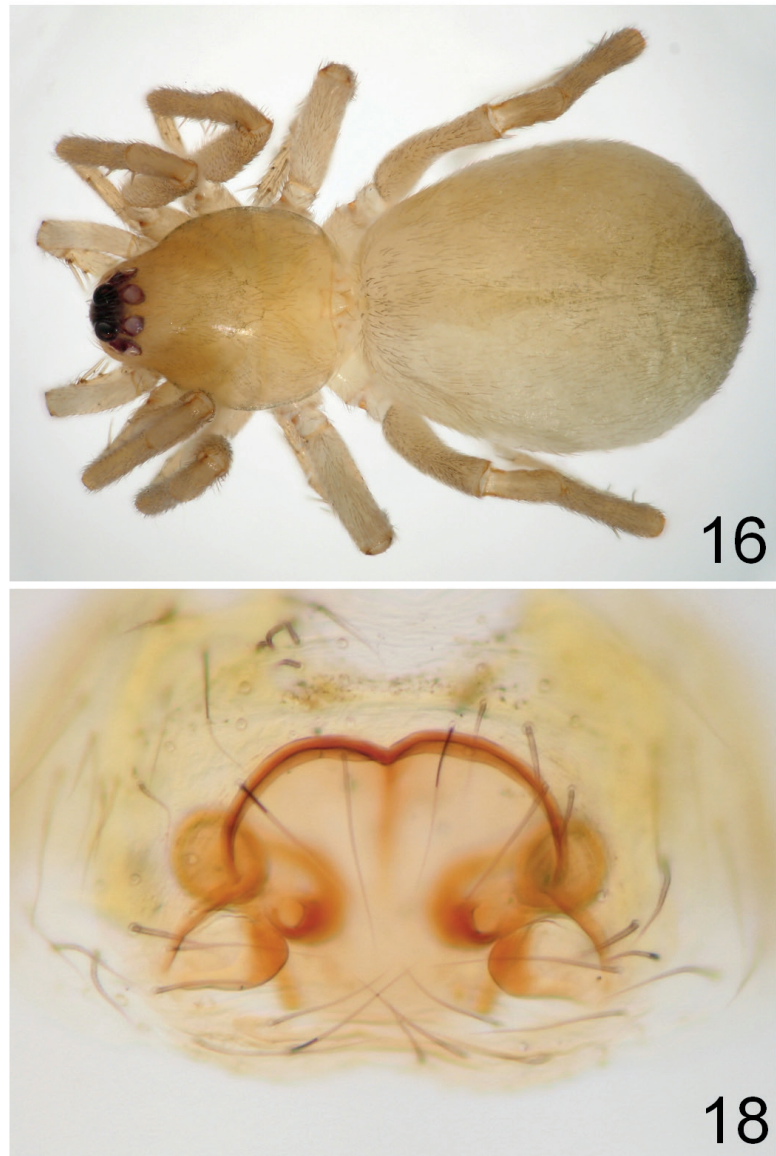

18

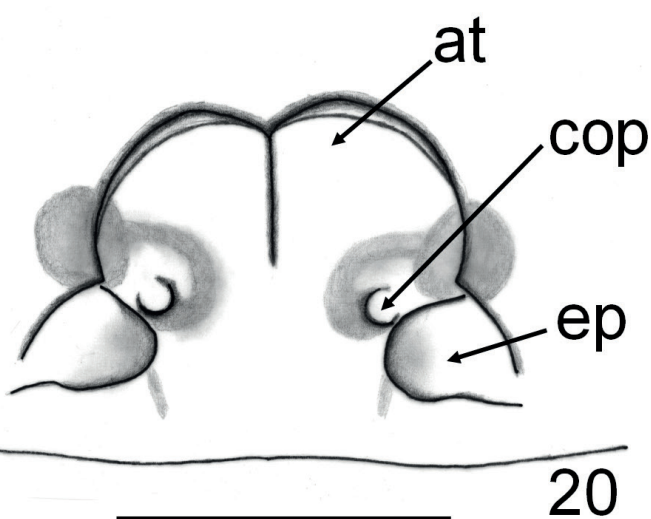

diameters and interdistances: AME 0.10, ALE 0.08, PME 0.08, PLE 0.08, AME-AME 0.08, AME-ALE 0.02, PME-PME 0.08, PME-PLE 0.04, ALE-PLE 0.01. Leg measurements: I - femur 0.76/ patella $0.36 /$ tibia 0.53 / metatarsus $0.46 /$ tarsus $0.36 /$ total 2.41 ; II $-0.76 /$ $0.36 / 0.59 / 0.46 / 0.36 / 2.47$; III - 0.62/ 0.30/ 0.46/ 0.43/ $0.30 / 2.11 ; \mathrm{IV}-0.99 / 0.36 / 0.76 / 0.79 / 0.30 / 3.20$. Leg spination: femora, I-IV d1-0-0, IV r0-0-1; tibiae, I-II v2-2-0, III v2-1-0, p1-1-1, IV v0-0-2, p0-0-1, r1-0-1; metatarsi, I-II v 2-0-0, III d0-1-2, v2-0-2, IV d2-0-2, v0-1-2, p1-0-0, r0-0-1. Palp spination: femur, d1-0-0; tibia, v1-0-0, p1-1-0; tarsus, d1-0-0, v1-0-2, p1-0-0, r1-0-0. Epigynal plate wider than long, semicircular
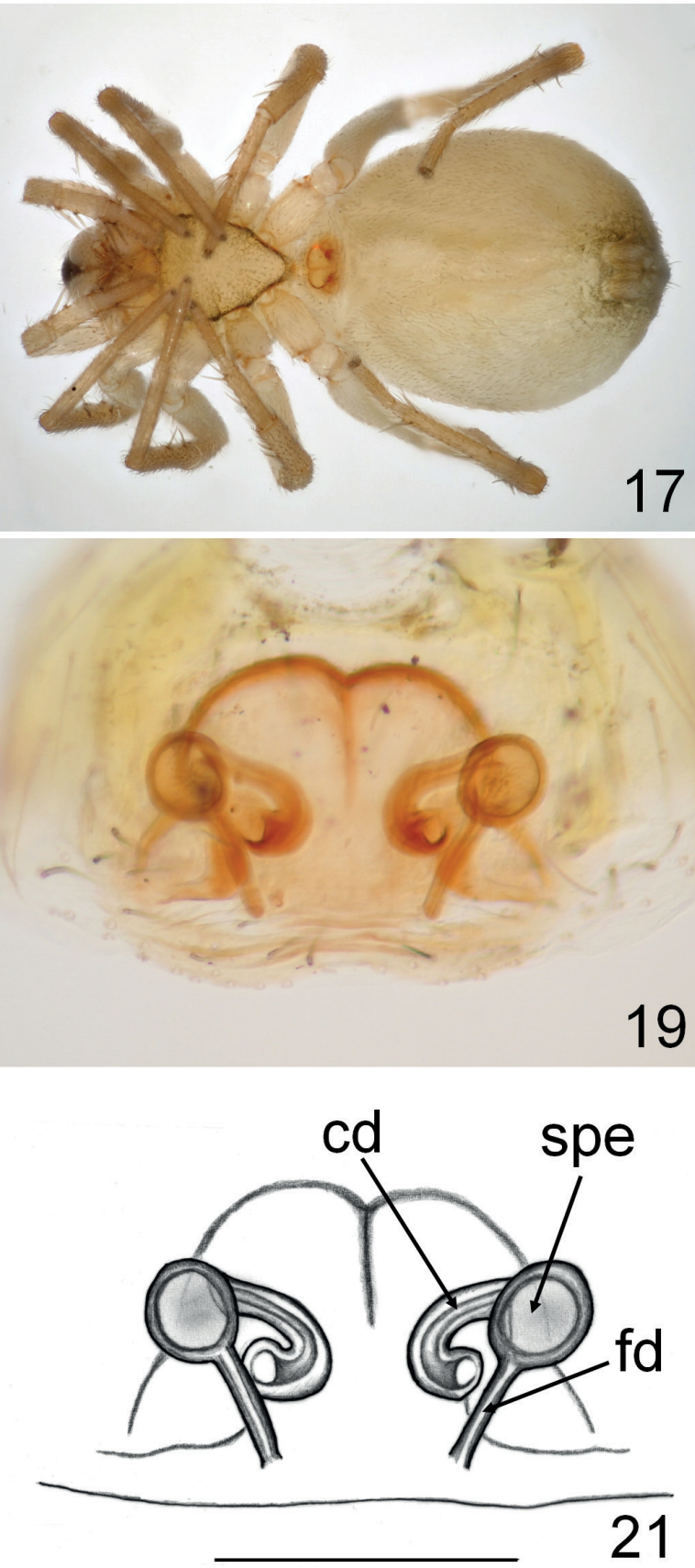

Figs 16-21. Neodrassex ibirapuita sp. nov. (holotype +, MCN 49393): 16, dorsal; 17, ventral; epigynum: 18, 20, ventral; 19, 21, dorsal. Scales = $0.20 \mathrm{~mm}$ (at, atrium; cd, copulatory ducts; cop, copulatory opening; ep, epigynal process; fd, fertilization ducts; spe, spermathecae). 

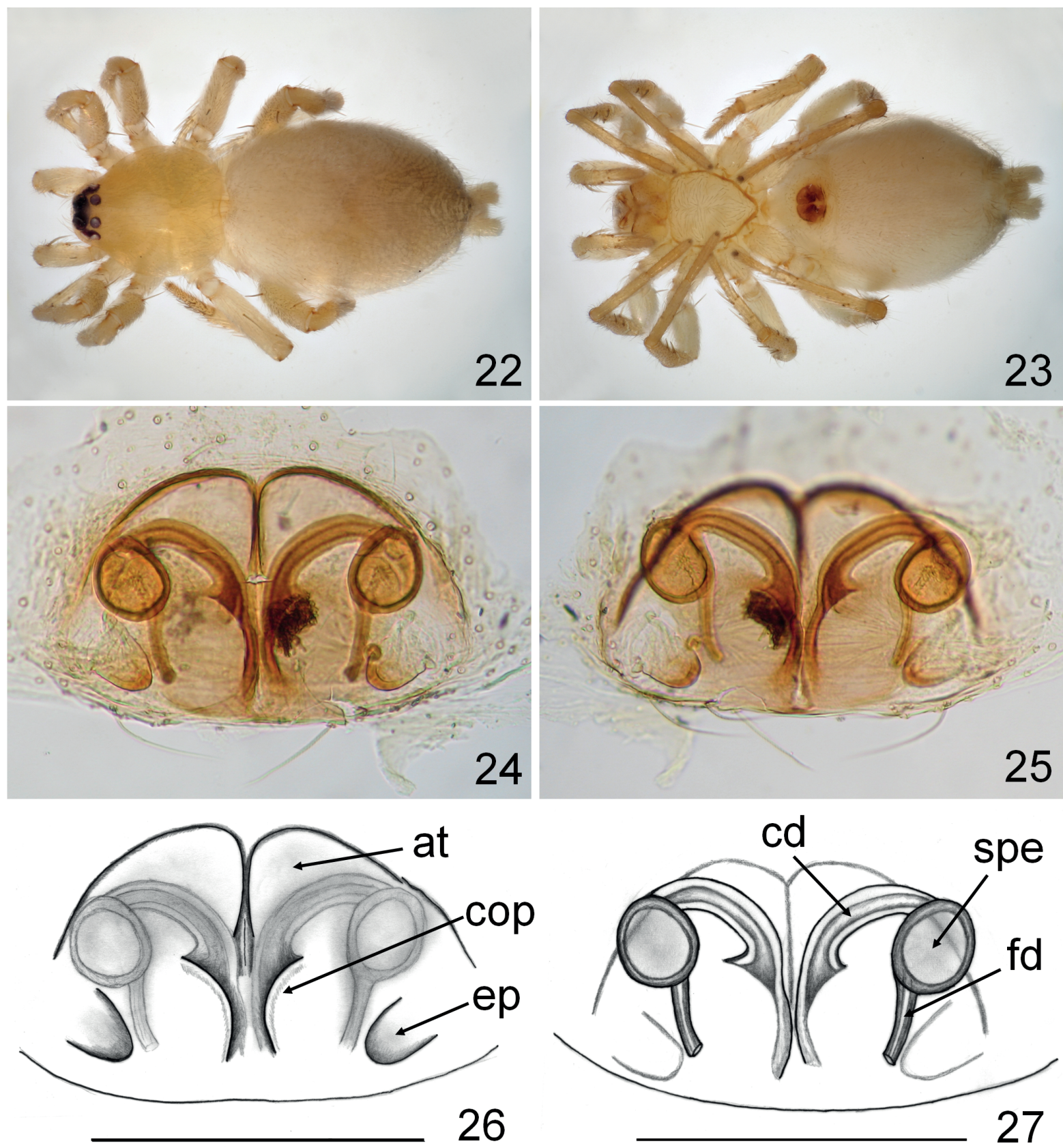

Figs 22-27. Neodrassex nordeste sp. nov. (22, 23, paratype +., MPEG 21486; 24-27, holotype 4 , MPEG 21487): 22, dorsal; 23, ventral; epigynum: 24,26 , ventral; 25,27 , dorsal. Scale $=0.20 \mathrm{~mm}$ (at, atrium; cd, copulatory duct; cop, copulatory opening; ep, epigynal process; fd, fertilization duct; spe, spermathecae).

atrium divided by narrow septum; copulatory openings extending from middle to the posterior portion of epigynum, larger than copulatory ducts in width; lateral epigynal processes slightly larger than copulatory duct width (Figs 24, 26); internal genitalia with relatively small, oval spermathecae; copulatory ducts relatively short, curved, narrowing slightly toward spermathecae, anterior portion broader; fertilization ducts posteriorly directed (Figs 25, 27).

Note. As in $N$. aureus females, can be found with large secretion plug on epigyna (Fig. 23).

Male. Unknown.
Distribution. Known only from the type locality. Natural history. Specimens collected in semiarid transition area between Cerrado and Caatinga Biomes using nocturnal manual sampling.

\section{DISCUSSION}

Отт (2012) raises considerable doubt on the biogeographic origin of Neodrassex species due to their suspected association to anthropic environments. The discovery of the herein described three new species in less disturbed habitats suggest that Neodrassex is a 
native representative of Neotropical fauna. Despite the somewhat larger numbers of available specimens and larger distribution range of $N$. aureus (OTT, 2012), the remaining species of Neodrassex are, until now, of very small distribution range and represented only by one or two specimens, considering it a very rare genus in collections. It is not impossible that any of available singlefemale species of the genus (N. iguatemi; N. ibirapuita sp. nov.; $N$. nordestina sp. nov.) could be conspecific with the single male of $N$. cachimbo sp. nov. However, this was considered unlikely based on the different type-locality environments and mainly the different cheliceral teeth pattern or femur IV dorsal spination (which, based on $N$. aureus, should be identical for males and females of a same species) of those species.
Acknowledgements. To CNPq/PELD for financial support of the project (Edital MCT/CNPq \# 59/2009). To Alexandre Bragio Bonaldo for the friendship, support and loan of specimens. To anonymous reviewers for helpful comments on the manuscript.

\section{REFERENCES}

Murphy, J. A. 2007. Gnaphosid genera of the world. St Neots, British Arachnological Society 1:I-XII, 1-92; 2:I-11, 93605.

Oтт, R. 2012. Neodrassex, a new genus of the Leptodrassex group (Araneae, Gnaphosidae) from South America. Iheringia, Série Zoologia 102(3):343-350.

Platnick, N. I. 2013. The world spider catalog, version 14. New York, American Museum of Natural History. Available at: $<\mathrm{http}: /$ research.amnh.org/entomology/spiders/catalog/index.html>. Accessed on: 10 October 2013. 